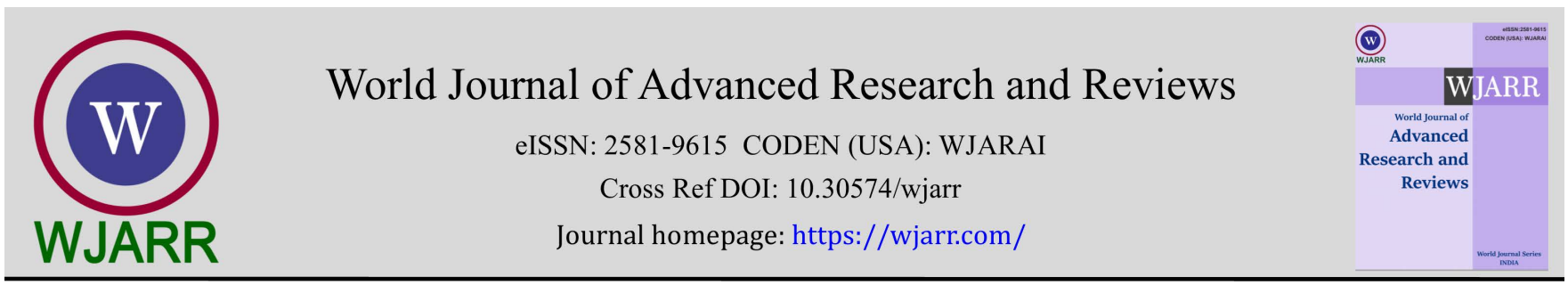

(REVIEW ARTICLE)

Check for updates

\title{
Food fraud: A menace to public health
}

\author{
Samiksha Sharma 1,* and Pragati Kaushal 2 \\ ${ }^{1}$ Department of Basic and Applied Sciences, National Institute of Food Technology Entrepreneurship and Management, \\ Sonipat, Haryana, India. \\ 2 Department of Food Science and Technology, Punjab Agricultural University, Ludhiana, Punjab, India.
}

World Journal of Advanced Research and Reviews, 2021, 12(03), 466-475

Publication history: Received on 01 November 2021; revised on 19 December 2021; accepted on 21 December 2021

Article DOI: https://doi.org/10.30574/wjarr.2021.12.3.0671

\begin{abstract}
Food is a basic requirement of people that helps in providing proper nutrition and energy for growth and repair of tissues. However, food which provides numerous health benefits now comes in adulterated form. Some of the most frequent products to be fraudulent are common to many households - olive oil, cheese, honey, herbs and spices etc. The greed of industries to gain higher profits within short period of time makes them to indulge in malpractices such as food fraud and involves such techniques for food fraud which go undetected even after using laboratory techniques. There are manifold analytical techniques to detect food fraud in laboratory but consumers are not able to detect it at home scale. Moreover, no one bothers to do that after buying it. Consuming a fraudulated food product can prove harmful for human body as it may have short term or long-term effects. It is only consumer awareness that can protect them from food fraud. The purpose of this review is to study the food fraud that is deliberately affecting the health of consumers.
\end{abstract}

Keywords: Food fraud; Adulteration; Dilution; Substitution; Addition; Detection

\section{Introduction}

Food is the prime need for every living being. Food for human consumption should be consumed in its possible purest form without adulterants. Food fraud is an old problem but major issue nowadays. Food fraud is an unlawful behavior which involves intentional substitution, addition, removal and misrepresentation of food. Fraud can occur in raw material, final product or packaging material. Food fraud in any of its forms causes a threat to food safety. Indian food market is not able to guarantee food safety.

There are number of instances of food frauds in India. Some of the examples from Indian food market are mentioned in this manuscript. The most common of all is milkman diluting milk with water. Water in milk may not harm our body but it will definitely reduce the nutritional value of milk. Moving towards next example as everyone knows, the purpose of food color is to make it look more attractive and appetizing but carcinogenic dyes such as sudan dyes are being added to paprika powder [1].

Turmeric which is considered as natural colorant is mixed with lead chromate to enhance its color which is harmful for human health [2]. Addition of harmful dyes is not just limited to spices but harmful colors such as carmine is also used as an artificial enhancement in black tea [3]. The most commonly adulterated foods are milk, honey, spices, oils, tea, coffee and cereals.

\footnotetext{
* Corresponding author: Samiksha Sharma

Department of Basic and Applied Sciences, National Institute of Food Technology Entrepreneurship and Management, Sonipat, Haryana, India.

Copyright (C) 2021 Author(s) retain the copyright of this article. This article is published under the terms of the Creative Commons Attribution Liscense 4.0.
} 
Food fraud is not just restricted to India but can be found anywhere in the world. Not only food but ingredients employed in medicines are also replaced by inferior ones. Chinese herbal medicine was found to be substituted with synthetic drugs and affected number of patients [4]. Mislabeling and false statements is new marketing glitch to befool consumers.

Though, there are number of techniques available which can test for food fraud such as Fourier transform infrared spectroscopy (FTIR), electronic nose, mass spectrometry, High performance liquid chromatography (HPLC) etc. But these techniques are performed in laboratories. It is difficult for a layman to detect whether food is fraudulent or not. We need to do more than standard setting. Food fraud is done to gain huge profits using terrible and illegal methods and most important of all consumers have very less awareness regarding food fraud.

\section{Classification of food frauds}

- $\quad$ Substitution: It includes substitution of inferior substances and removing the valuable ones. This is clearly explained from following example:

HORSE MEAT SCANDAL, 2013: In Ireland, country's food safety authority tested frozen meat and beef products available in supermarket. The organization identified horse DNA in over one- third beef burgers.

- $\quad$ Dilution: Dilution is done to increase the volume of food product like addition of water to milk.

- $\quad$ Artificial enhancement: Coloring a food product or adding an ingredient to make it look more appealing. For instance, to enhance the color of paprika, sudan dyes are added to it.

- $\quad$ Counterfeiting: To mimic something original with the aim to deceive consumers to trust that fake is of equal or greater value than the original thing. For example, dried flowers and dyed onion being sold as saffron.

- $\quad$ Mislabeling: Intentionally wrong labeling of the food product for financial gain with the intention of deceiving the consumer concerning what is originally packaged. Example:

MISLABELED OLIVE OIL: When a good quality product is available at cheap prices one should be doubtful.

- $\quad$ False marketing: Advertising false statements for the sale of food product. Example:

Apple juice scandal, 1987: Beech-Nut a company in US was fined \$ 2 million for intentionally making false statement that their product is " $100 \%$ apple juice" which actually contained water, corn syrup, and cane syrup and beet sugar.

\section{Food fraud detection in different food samples}

There are number of techniques available to detect food fraud at laboratory level. Some of them are described below.

\subsection{Meat}

Von Bargen et al. [5] detected pork and horse in halal beef using high performance liquid chromatography (HPLC). It separates different samples on the basis of their difference in relative affinities for molecules in mobile and stationary phase used in separation. Mass spectrometry was also used to detect the same. In mass spectrometry, samples generate ions which are separated according to specific charge to mass ratio and separated according to relative abundance.

Goat meat adulteration with pork was determined by Wang et al. [6] using real time- polymerase chain reaction (RTPCR). In RT-PCR using reverse transcriptase, RNA template is converted to complementary DNA followed by amplification using PCR using complementary DNA as a template. At the end, RT-PCR gave better results than conventional PCR.

\subsection{Honey}

Subari et al. [7] collected different brands of pure honey samples. Honey samples were adulterated in different concentrations. Honey adulteration tests were performed using electronic nose (e-nose) and Fourier transform infrared spectroscopy (FTIR). However, FTIR was found to be more accurate than e-nose. In FTIR, infrared radiation is passed through sample. When frequency of infrared radiation matches the natural frequency of bond, the amplitude of vibration increases and infrared is absorbed. The output is in the form of chart for infrared spectrophotometer. E-nose is designed to recognize the harmful substance in product, also to recognize the flavor and odor. E-nose functions similar to nose of human. It uses sensors when sensors receive the molecules, then the signal is transmitted to program for processing and hence analyze the product. 
Alghamdi et al. [8] detected the presence of added sugar and pesticides in honey using HPLC (High performance liquid chromatography) and GC-MS (Gas chromatography- mass spectrometry) technique respectively. Fourteen honey samples were collected from the market of Saudi Arabia and tested which revealed that two samples contained sucrose but in acceptable limits. Only one sample contained $15.95 \mathrm{ppb}$ hexachlorobenzene (fungicide used on crops to control fungal disease, pollinators such as honey bees get tainted with pesticides which can get into the honey) per kilogram of honey. However, samples collected from the market conform to the standards of the regional and international standardization organization, the GSO and Codex Alimentarius Commission respectively. GC-MS separates the product according to their difference in boiling point or size. At low temperatures, the sample components having low boiling point are eluted first.

Adulterants such as fructose and surcrose were detected in pure honey by Yadav et al. [9] using fiber optic surface plasmon resonance (SPR) sensor using silver and silver -graphene oxide. This technique proved to be an effective method in adulterants detection. In SPR, there is interaction of light and free electrons present in semi-transparent metal layer which is placed on dielectric substrate. When refractive index of dielectric medium changes, there is a change in resonance which is exhibited at particular wavelength.

\subsection{Milk}

Melamine is added to milk for increasing protein content of milk. Single bounce attenuated total reflectance (SB-ATR) Fourier transform infrared spectroscopy (FTIR) was used by Jawaid et al. [10] to detect the presence of melamine in milk. In FTIR, depending on type of bonds and elements, molecular bonds vibrate at different frequencies.

3-amino-1, 2, 4-triazine (ATZ) is an organic compound added in milk to increase nitrogen which will show increase in protein content. ATZ is oxidized to (3-amino-1, 2, 4-triazin-5-one) ATZO in milk which can be detected using high resolution mass spectrometry and fragmentation analysis. Abernethy and Higgs [11] concluded that detection of ATZO in milk indicates the presence of ATZ in milk. In mass spectrometry, sample generates number of ions which gets separated on basis of mass to charge ratio and then relative abundance of each ion type is studied. Further, in fragmentation analysis, fragmentation pattern of unstable molecules was studied to determine the structural information and molar weight of molecule.

Ghodinde and Chaskar [12] detected urea in cow milk using impedence spectroscopy. In this, impedence of the milk is converted to voltage. The changes in impedence further changes phase angle of output signal. There is a change in impedence, resistance and phase angle due to adulteration, thereby indicating the presence of urea in milk. Agharkar and Mane [13] identified a cost-effective method of detecting formalin in milk even at the lower concentrations using small quantity of solution of gold nanoparticles.

\subsection{Oil}

The dilution of avocado oil with edible oil such as canola, sunflower and soybean oil can be tested using SIMCA (Soft Independent Modeling Class Analogy) method [14]. SIMCA is statistical method of machine learning of data. The software identifies the sample belonging to different classes.

De Lima et al. [15] used Raman spectroscopy to identify rapeseed oil and corn oil as adulterants in olive oil. This method does not require any sample treatment for detection of an adulterant in liquid molecular environment. Raman spectroscopy tells us about chemical and structural information with shift in the wavelength of scattered radiation. Low frequency dielectric spectroscopy with chemometrics was used for detection of rapeseed oil in sesame oil. It is cheap and fast method. Dielectric spectroscopy is based on interaction of charges and electric dipole of the medium with an external electric field. It measures electric and dielectric properties of medium as function of time [16].

\subsection{Spices}

Chili which is used in number of food products from 2003 onwards was found to be dyed with sudan dyes for enhancing its color. Near infrared reflectance spectroscopy (NIRS) and Raman spectroscopy was used to detect sudan dye in chili powder. Though, NIRS was found to be more suitable for detection as compared to Raman spectroscopy. In NIRS, electromagnetic radiations are absorbed by the sample. Energy is absorbed in NIR when molecules vibrate or translated into absorption spectrum [17]. In Raman spectroscopy, a monochromatic light is passed through the sample, which interacts with it. Light is reflected, absorbed or scattered in some manner. It is the scattering of light which gives us information regarding molecular structure of compound. 
Black pepper is most extensively used spice in the world. Black pepper is diluted with husk, defatted spent materials, and pinheads. Moreover, black pepper can also be substituted with chili, papaya seeds. Wilde et al. [18] screened black pepper using near and Fourier-Transform Infrared Spectroscopy.

Paranthaman et al. [19] used X-ray diffraction method to detect lead chromate in turmeric powder. X-ray diffraction uses less sample size, has good detection limit, provide good resolution and high sensitivity. Mor eover, it does not require sample preparation. The amount of material in the mixture is proportional to intensities of diffraction peaks.

\subsection{Coffee}

Souto et al. [20] identified dilution of coffee with husk and dust using UV-VIS spectroscopy. Husk and dust is added to increase the quantity of coffee. UV-VIS (Ultraviolet-visible) spectroscopy involves the absorption of ultraviolet light by molecules causing bonding and non -bonding electrons to absorb energy and undergo transition from ground state to excited state.

Although there are a lot of methods to detect food fraud but still such frauds remain invisible to a layman but it can have long term effects which are presented below in Table 1. The ones which show short term effect may not be that harmful as compared to the ones which are stable and will show long term and dangerous effects.

Table 1 Food fraud in products along with their harmful effects

\begin{tabular}{|c|c|c|c|c|}
\hline $\begin{array}{l}\text { S. } \\
\text { No. }\end{array}$ & Food products & Type of food fraud & Harmful effects & Reference \\
\hline 1. & Edible oil & $\begin{array}{l}\text { (Argemone oil, castor oil, } \\
\text { vanaspati, mineral oil) Dilution }\end{array}$ & $\begin{array}{l}\text { Acute renal failure, carcinogenic } \\
\text { effects, stomach infection, heart } \\
\text { disease, loss of eyesight, liver damage, } \\
\text { tumor }\end{array}$ & [21] \\
\hline \multirow[t]{2}{*}{2.} & Honey & (Molasses sugar) Dilution & Stomach problems & [21] \\
\hline & & $\begin{array}{l}\text { (Addition of antibiotics) } \\
\text { Artificial enhancement }\end{array}$ & Resistance to antibiotics & [22] \\
\hline 3. & Ghee & (Vanaspati) Dilution & Renal failure & [21] \\
\hline 4. & Salt & (Chalk powder) Substitution & Stomach disorder & [21] \\
\hline 5. & Jaggery & (Washing soda, chalk powder) & Vomiting, diarrhea & [21] \\
\hline 6. & Juices & $\begin{array}{l}\text { (Clouding agents) Artificial } \\
\text { enhancement }\end{array}$ & $\begin{array}{l}\text { Carcinogenic, affect reproductive } \\
\text { tract }\end{array}$ & [23] \\
\hline \multirow[t]{4}{*}{7.} & \multirow[t]{4}{*}{ Tea / Coffee } & $\begin{array}{l}\text { (Presence of chicory) Dilution, } \\
\text { Mislabeling }\end{array}$ & Stomach infection & [24] \\
\hline & & $\begin{array}{l}\text { (Coal tar dye) Artificial } \\
\text { enhancement }\end{array}$ & Carcinogenic & [24] \\
\hline & & $\begin{array}{l}\text { (Iron fillings, sand, cereal } \\
\text { starch) Dilution, Mislabeling }\end{array}$ & Digestive problems & [24] \\
\hline & & $\begin{array}{l}\text { (Artificial color) Artificial } \\
\text { enhancement }\end{array}$ & Carcinogenic & [24] \\
\hline \multirow[t]{3}{*}{8.} & \multicolumn{4}{|c|}{ Milk and milk products } \\
\hline & Milk & (Water addition) Dilution & Malnutrition & [25] \\
\hline & & $\begin{array}{l}\text { (Sugars- To increase lactometer } \\
\text { reading and hide dilution with } \\
\text { water) } \\
\text { Artificial enhancement }\end{array}$ & $\begin{array}{l}\text { Harmful for diabetic patients, also } \\
\text { pose risk by making people consume } \\
\text { more sugars than recommended daily } \\
\text { intake }\end{array}$ & [26] \\
\hline
\end{tabular}




\begin{tabular}{|c|c|c|c|c|}
\hline & & (Vegetable oil) Dilution & \multirow{2}{*}{$\begin{array}{l}\text { Vomiting, wheezing throat, harmful } \\
\text { for patients having nut allergy. } \\
\text { Toxic poisoning, affects digestive and } \\
\text { excretory system }\end{array}$} & \multirow{2}{*}{$\begin{array}{l}{[26]} \\
{[26]}\end{array}$} \\
\hline & & $\begin{array}{l}\text { (Urea and melamine- to } \\
\text { increase protein content in } \\
\text { milk) Artificial enhancement }\end{array}$ & & \\
\hline & & $\begin{array}{l}\text { (Detergents- increasing profits } \\
\text { by cosmetic enhancement) } \\
\text { Artificial enhancement }\end{array}$ & $\begin{array}{l}\text { Digestive and respiratory problems } \\
\text { and can be carcinogenic. }\end{array}$ & {$[26]$} \\
\hline & $\begin{array}{l}\text { Ultra-high } \\
\text { temperature } \\
\text { milk }\end{array}$ & $\begin{array}{l}\text { Addition of urine, chlorine, } \\
\text { hydrogen peroxide and } \\
\text { formaldehyde) } \\
\text { enhancement }\end{array}$ & $\begin{array}{l}\text { Affects excretory system and } \\
\text { digestive system, vomiting, burns } \\
\text { mucosa of oesophagus and lips. }\end{array}$ & {$[27]$} \\
\hline & Milk powder & $\begin{array}{l}\text { (Addition of non- milk fats and } \\
\text { oils) Dilution }\end{array}$ & $\begin{array}{l}\text { Vomiting, coughing and wheezing } \\
\text { throat. }\end{array}$ & [28] \\
\hline \multirow[t]{5}{*}{9.} & \multicolumn{4}{|c|}{ Meat and meat products } \\
\hline & Fish -Sardines & $\begin{array}{l}\text { (Mixing with other species) } \\
\text { Substitution Counterfeit }\end{array}$ & Decreased nutritional value & {$[29]$} \\
\hline & Meat & $\begin{array}{l}\text { (DNA of chicken in pork } \\
\text { sausage) Dilution }\end{array}$ & Decreased nutritional value. & [5] \\
\hline & Beef hamburger & $\begin{array}{l}\text { (Addition of soy protein) } \\
\text { Dilution }\end{array}$ & Decreased nutritional value & \\
\hline & Beer & $\begin{array}{l}\text { (Changing the caps of less } \\
\text { expensive brand with more } \\
\text { expensive on) Counterfeit }\end{array}$ & $\begin{array}{l}\text { Affects excretory and digestive } \\
\text { system }\end{array}$ & {$[30]$} \\
\hline \multirow[t]{4}{*}{10.} & \multicolumn{4}{|c|}{ Cereals, pulses and other products } \\
\hline & Rice/ Puffed rice & $\begin{array}{l}\text { (For white color) Artificial } \\
\text { enhancement }\end{array}$ & Excretory and digestive issues & \\
\hline & $\begin{array}{l}\text { Toor dhal and } \\
\text { Bengal gram } \\
\text { dhal }\end{array}$ & (Kesari dhal) Dilution & Lathyrism & \\
\hline & Arhar dhal & $\begin{array}{l}\text { (Metanil yellow) Artificial } \\
\text { enhancement }\end{array}$ & Neurotoxicity & \\
\hline \multirow[t]{6}{*}{11.} & \multicolumn{4}{|l|}{ Spices } \\
\hline & Black pepper & (Papaya seeds) Dilution & Liver and digestive problems & {$[31]$} \\
\hline & Mustard seeds & (Argemone seeds) Dilution & Glaucoma & {$[32]$} \\
\hline & Asafoetida & (Foreign resin) Dilution & Dysentery & {$[32]$} \\
\hline & $\begin{array}{l}\text { Turmeric } \\
\text { powder }\end{array}$ & $\begin{array}{l}\text { (Yellow dyes) Artificial } \\
\text { enhancement }\end{array}$ & Carcinogenic & {$[33]$} \\
\hline & Chili powder & $\begin{array}{l}\text { (Artificial colors, brick powder } \\
\text { and saw dust) Artificial } \\
\text { enhancement }\end{array}$ & Cancer and stomach problems & [33] \\
\hline 12. & Almond powder & (Peanut powder) Substitution & Allergy & {$[34]$} \\
\hline
\end{tabular}

\subsection{Wheat}

Antoine et al. [35] detected peanut flour as an adulterant in wheat flour using matched subspace detector (MSD) algorithm and near infrared as shown in Figure 1. MSD is designed in such a way so that it could overcome the challenges 
faced during peanut flour detection i.e., similar spectral variability and signatures is exhibited by wheat and peanut flour and second is impure spectral profiles can be obtained as particle size of peanut flour was smaller than pixel size.

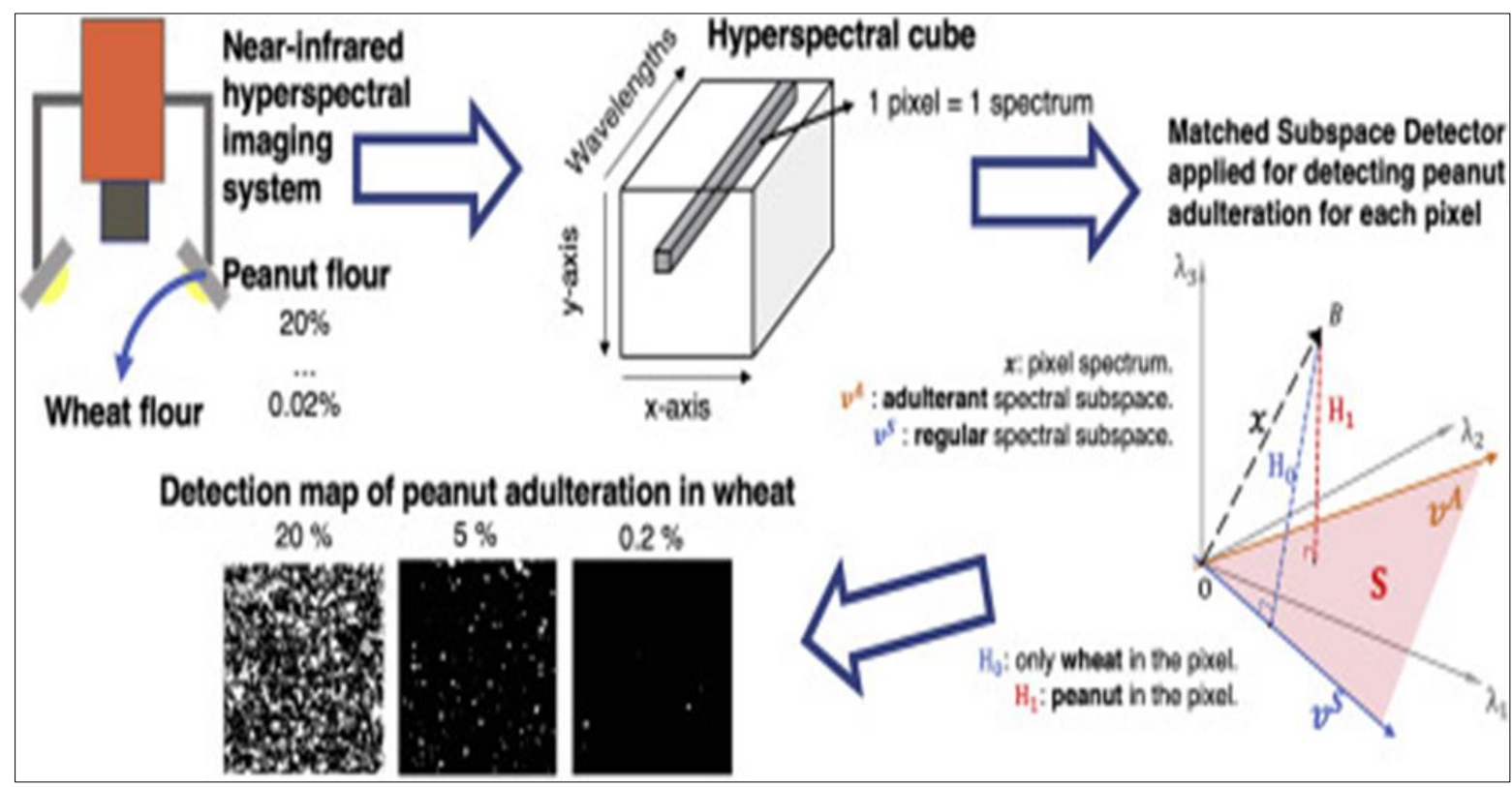

Figure 1 Detection map of peanut adulteration in wheat [35]

\section{False marketing and mislabelling: befooling consumers}

Food companies advertise their products through radio, television, banners, newspapers etc. but sometimes mislead the consumers by giving false statements without any scientific proof which is illegal under the FSS act, Section 24. There are manifold instances which fall under the same category and violate FSS act, 2006 under section 24 . Some of them are mentioned in Table 2 .

Table 2 Companies and their false claims [36]

\begin{tabular}{|l|l|}
\hline Company & Claims \\
\hline Complan & Devouring it two times, one can grow faster. \\
\hline Kellogg's & Special K claims that people who eat their product tend to get slim than those who don't \\
\hline Bournvita & Bournvita little champs claims that DHA present in it has copious benefits which are not proven yet \\
\hline $\begin{array}{l}\text { Britannia's } \\
\text { nutrichoice }\end{array}$ & $\begin{array}{l}\text { The company advertises that its biscuits have no added sugar and complex carbohydrates which is } \\
\text { good for diabetic patients. }\end{array}$ \\
\hline Kissan & Cream spread claims that it has more nutrients than sadharan butter. \\
\hline
\end{tabular}

$53 \%$ children consume packaged food once or even twice day. Mortality due to poor diet is $50 \%$ higher than tobacco and alcohol. Packaged food is more in demand because of its convenience, cheap prices and palatability. Consumers don't want to fall ill but their knowledge related to food labeling is so poor that they are not able to support their notion of being healthy. Consumers are able to study expiry date but fail to study masquerading ingredients or amount of tran's fats or other ingredients which are available per serving. There are many companies labeling on their products 'No trans fats' which draw a lot of consumer attention. Tran's fats are present in crackers, biscuits, fried foods, vegetable shortening, margarine and many more. One of the problems with Tran's fats is associated with heart disease [36] and Trans fats inhibit omega-3 fatty acids which help in curing depression [37], reduce aggressiveness and provide saneness [38]. 
These companies attract the consumers with good marketing. Hence, the malicious effects of the products are overshadowed by effective marketing gimmick. Consumers generally look for good quality and appearance which gives them satisfaction and no one really bothers to check if food is fraudulent or not. Besides that, from a practical perspective it is arduous for consumers to tell if food is fraudulent even after consumption. Consumer's awareness is good related to rights but poor related to food fraud [39]. To combat with this issue, consumers should take a look at price if it seems too good to be true. One should be skeptical while buying a high rated product at cheap price. Consumers should check if any information on label is misleading. Consumers should question companies about the food product when in doubt. It will make companies more vigilant about food fraud. The summary of different research on food fraud along with their outcomes is represented in Table 3 as under.

Table 3 Different research on food fraud and their outcomes

\begin{tabular}{|c|c|c|c|}
\hline S. No. & Aim of research & Outcomes & Source \\
\hline 1. & $\begin{array}{l}\text { Level and type of synthetic color added to } \\
\text { eatables in rural and urban area in Lucknow }\end{array}$ & $\begin{array}{l}\text { Synthetic colors were beyond the acceptable } \\
\text { limit mostly in rural areas. }\end{array}$ & {$[40]$} \\
\hline 2. & $\begin{array}{l}\text { Detection of starch in granular powder of herb } \\
\text { using NIR combining chemometric techniques }\end{array}$ & $\begin{array}{l}\text { NIR combined with chemometric technique } \\
\text { is quick, easy and dependable technique }\end{array}$ & {$[41]$} \\
\hline 3. & $\begin{array}{l}\text { Detection of starch in lotus root powder using } \\
\text { FT-MIR spectroscopy in combination of } \\
\text { chemometric technique }\end{array}$ & $\begin{array}{l}\text { FT-MIR (Fourier transform mid-infrared } \\
\text { spectroscopy) spectroscopy is fast and } \\
\text { simple technique for detection of starch in } \\
\text { lotus root powder }\end{array}$ & {$[42]$} \\
\hline 4. & $\begin{array}{l}\text { Diagnosis of different sugar syrups in honey } \\
\text { using NIR spectroscopy in combination with } \\
\text { aquaphotomics }\end{array}$ & $\begin{array}{l}\text { NIR spectroscopy in combination with } \\
\text { aquaphotomics was found to be useful one. }\end{array}$ & {$[43]$} \\
\hline 5. & $\begin{array}{l}\text { Detection of fish oil diluted with terrestrial } \\
\text { animal lipid using FT-IR spectroscopy }\end{array}$ & $\begin{array}{l}\text { FT-IR spectroscopy proved to be useful for } \\
\text { detection of terrestrial animal lipid in fish } \\
\text { oil. }\end{array}$ & {$[44]$} \\
\hline 6. & $\begin{array}{l}\text { Detection of counterfeited fish using genomic } \\
\text { DNA and PCR amplification of } 5 \text { s rRNA gene }\end{array}$ & $\begin{array}{l}\text { Genomic DNA and PCR amplification of } 5 \mathrm{~s} \\
\text { rRNA gene helps in detection of } \\
\text { counterfeited fish species }\end{array}$ & [45] \\
\hline 7. & $\begin{array}{l}\text { Diagnosis of seagull meat in meat product using } \\
\text { PCR }\end{array}$ & $\begin{array}{l}\text { PCR is fast and sensitive method to detect } \\
\text { substitution seagull in meat products. }\end{array}$ & [46] \\
\hline 8. & DNA barcoding to find the mislabeled fish & $\begin{array}{l}\text { DNA bar coding detected } 47 \% \text { of mislabeled } \\
\text { sushi grade fish. }\end{array}$ & {$[29]$} \\
\hline 9. & $\begin{array}{l}\text { Extent of awareness among people regarding } \\
\text { food fraud. }\end{array}$ & $\begin{array}{l}\text { People have low awareness about food } \\
\text { fraud. }\end{array}$ & [39] \\
\hline 10. & $\begin{array}{l}\text { Determination of peanut and green pea as } \\
\text { adulterant in pistachio using Fourier transform } \\
\text { near-infrared (FT-NIR) spectroscopy and } \\
\text { Fourier transform mid-infrared (FT-MIR). }\end{array}$ & $\begin{array}{l}\text { FT-NIR and FT-MIR proved more } \\
\text { manageable, economic and fast method as } \\
\text { compared to gas chromatography (GC) and } \\
\text { high performance liquid chromatography } \\
\text { (HPLC). }\end{array}$ & [47] \\
\hline
\end{tabular}

\section{Conclusion}

It can be concluded from various studies that food fraud is being widely done. Moreover, people are becoming avaricious to gain more profits without concerning about the health of consumers. There are manifold analytical techniques which can detect food fraud. So, the companies should check the raw material if there is any kind of food fraud. For example, farmers providing milk to companies may add oil to increase its fat content which will help them to gain higher profits. Companies should responsibly analyze the quality of raw material provided. Moreover, more instruments like as Test0-Milk Strip Based Milk Testing Kit should be made or some colored strips should be made to detect safety of product in affordable price. Such instruments make consumer's task easy to detect safety of food and which will help in partially avoiding food fraud. Although, various food detection techniques are available at FSSAI (Food safety and standards authority of India) site which can be done at home but no one bothers to do it after purchasing it. So, in case of 
restaurants, food safety officers should regularly and honestly audit it. In addition, fraudulent food may not show immediate effect but constant devouring of such food may sway consumers towards poor health. So, food fraud can only be eliminated with consumer awareness. Moving ahead, Consumers should doubt on safety of food if prices seem good to be true. In any kind of fraud, companies should be questioned about it. However, food fraud will never come to end if honest and proper testing will not be done by the companies which can be seen in recent instance of honey adulteration in India.

\section{Compliance with ethical standards}

\section{Disclosure of conflict of interest}

There is no conflict of interest.

\section{References}

[1] Hu Y, Wang S, Wang S, Lu X. Application of nuclear magnetic resonance spectroscopy in food adulteration determination: the example of Sudan dye I in paprika powder. Scientific reports. 2017 Jun 1; 7(1):1-9.

[2] Erasmus SW, van Hasselt L, Ebbinge LM, van Ruth SM. Real or fake yellow in the vibrant colour craze: Rapid detection of lead chromate in turmeric. Food Control. 2021 Mar 1;121:107714.

[3] Wei L, Yang Y, Sun D. Rapid detection of carmine in black tea with spectrophotometry coupled predictive modelling. Food Chemistry. 2020 Nov 1;329:127177.

[4] Ernst E. Adulteration of Chinese herbal medicines with synthetic drugs: a systematic review. Journal of internal medicine. 2002 Aug;252(2):107-13.

[5] von Bargen C, Dojahn J, Waidelich D, Humpf HU, Brockmeyer J. New sensitive high-performance liquid chromatography-tandem mass spectrometry method for the detection of horse and pork in halal beef. Journal of agricultural and food chemistry. 2013 Dec 11;61 (49):11986-94.

[6] Wang Z, Wang Z, Li T, Qiao L, Liu R, Zhao Y, Xu Z, Chen G, Yang S, Chen A. Real-time PCR based on single-copy housekeeping genes for quantitative detection of goat meat adulteration with pork. International Journal of Food Science \& Technology. 2020 Feb;55 (2):553-8.

[7] Subari N, Mohamad Saleh J, Md Shakaff AY, Zakaria A. A hybrid sensing approach for pure and adulterated honey classification. Sensors. 2012 Oct;12(10):14022-40.

[8] Alghamdi BA, Alshumrani ES, Saeed MS, Rawas GM, Alharthi NT, Baeshen MN, Helmi NM, Alam MZ, Suhail M. Analysis of sugar composition and pesticides using HPLC and GC-MS techniques in honey samples collected from Saudi Arabian markets. Saudi Journal of Biological Sciences. 2020 Dec 1;27(12):3720-6.

[9] Yadav MK, Kumar P, Verma RK. Detection of adulteration in pure honey utilizing Ag-graphene oxide coated fiber optic SPR probes. Food Chemistry. 2020 Dec 1;332:127346.

[10] Jawaid S, Talpur FN, Sherazi ST, Nizamani SM, Khaskheli AA. Rapid detection of melamine adulteration in dairy milk by SB-ATR-Fourier transform infrared spectroscopy. Food chemistry. 2013 Dec 1;141(3):3066-71.

[11] Abernethy G, Higgs K. Detection of 3-amino-1, 2, 4-triazine adulteration in milk using an oxidation product 3amino-1, 2, 4-triazin-5 (2H)-one. Journal of Chromatography A. 2013 Apr 12;1285:165-7.

[12] Ghodinde KA, Chaskar UM. Quantification of Urea Adulteration with Impedance Spectroscopy in Cow Milk. In2021 6th International Conference for Convergence in Technology (I2CT) 2021 Apr 2 (pp. 1-5). IEEE.

[13] Agharkar M, Mane S. Utilization of gold nanoparticles to detect formalin adulteration in milk. Materials Today: Proceedings. 2021 Feb; 45(6): 4421-3.

[14] Quiñones-Islas N, Meza-Márquez OG, Osorio-Revilla G, Gallardo-Velazquez T. Detection of adulterants in avocado oil by Mid-FTIR spectroscopy and multivariate analysis. Food Research International. 2013 Apr 1;51(1):148-54.

[15] de Lima TK, Musso M, Menezes DB. Using Raman spectroscopy and an exponential equation approach to detect adulteration of olive oil with rapeseed and corn oil. Food Chemistry. 2020 Dec 15;333:127454.

[16] Firouz MS, Rashvand M, Omid M. Rapid identification and quantification of sesame oils adulteration using low frequency dielectric spectroscopy combined with chemometrics. LWT. 2021 Apr 1;140:110736. 
[17] Haughey SA, Galvin-King P, Ho YC, Bell SE, Elliott CT. The feasibility of using near infrared and Raman spectroscopic techniques to detect fraudulent adulteration of chili powders with Sudan dye. Food control. 2015 Feb 1;48:75-83.

[18] Wilde AS, Haughey SA, Galvin-King P, Elliott CT. The feasibility of applying NIR and FT-IR fingerprinting to detect adulteration in black pepper. Food Control. 2019 Jun 1;100:1-7.

[19] Paranthaman R, Moses JA, Anandharamakrishnan C. Development of a method for qualitative detection of lead chromate adulteration in turmeric powder using X-ray powder diffraction. Food Control. 2021 Aug 1;126:107992.

[20] Souto UT, Barbosa MF, Dantas HV, de Pontes AS, da Silva Lyra W, Diniz PH, de Araújo MC, da Silva EC. Screening for coffee adulteration using digital images and SPA-LDA. Food Analytical Methods. 2015 Jul;8(6):1515-21.

[21] Navya P, Raju K, Sukumaran MK. Analysis of food adulterants in selected food items purchased from local grocery stores. International Journal of Advances in Scientific Research. 2017;3(07):82-9.

[22] Reybroeck W. Residues of antibiotics and sulphonamides in honey on the Belgian market. group. 2002 Jan 1;200:50.

[23] Yang J, Hauser R, Goldman RH. Taiwan food scandal: The illegal use of phthalates as a clouding agent and their contribution to maternal exposure. Food and chemical toxicology. 2013 Aug 1;58:362-8.

[24] Pal AD, Das T. Analysis of adulteration in black tea. International Journal of Biology. 2018;3(1):253-7.

[25] Caldeira LA, ROCHA JÊNIOR VR, Fonseca CM, Melo LM, Cruz AG, Oliveira LD. Caracterização do leite comercializado em Janaúba-MG Characterization of milk commercialized in Janaúba-MG. Alimentos e Nutrição Araraquara. 2010 Nov 16;21(2):191-6.

[26] Barham GS, Khaskheli M, Soomro AH, Nizamani ZA. Risk of adulteration in milk consumed at Shaheed Benazirabad District of Sindh. International Journal of Adulteration. 2015; 1: 31-7.

[27] Souza SS, Cruz AG, Walter EH, Faria JA, Celeghini RM, Ferreira MM, Granato D, Sant'Ana AD. Monitoring the authenticity of Brazilian UHT milk: A chemometric approach. Food chemistry. 2011 Jan 15;124(2):692-5.

[28] Garcia JS, Sanvido GB, Saraiva SA, Zacca JJ, Cosso RG, Eberlin MN. Bovine milk powder adulteration with vegetable oils or fats revealed by MALDI-QTOF MS. Food Chemistry. 2012 Mar 15;131(2):722-6.

[29] Willette DA, Simmonds SE, Cheng SH, Esteves S, Kane TL, Nuetzel H, Pilaud N, Rachmawati R, Barber PH. Using DNA barcoding to track seafood mislabeling in Los Angeles restaurants. Conservation Biology. 2017 Oct;31(5):1076-85.

[30] Pereira HV, Amador VS, Sena MM, Augusti R, Piccin E. Paper spray mass spectrometry and PLS-DA improved by variable selection for the forensic discrimination of beers. Analytica Chimica Acta. 2016 Oct 12;940:104-12.

[31] Dhanya K, Syamkumar S, Sasikumar B. Development and application of SCAR marker for the detection of papaya seed adulteration in traded black pepper powder. Food Biotechnology. 2009 May 11;23(2):97-106.

[32] Deb U, Mishra BK. Detection of Adulterants in Selected Spices Sold in Garo Hills, Meghalaya. Journal of Agroecology and Natural Resource Management. 2019; 6(2): 44-7.

[33] Jaiswal S, Yadav DS, Mishra MK, Gupta AK. Detection of adulterants in spices through chemical method and thin layer chromatography for forensic consideration. Int J Dev Res. 2016 Jun 19;6(08):8824-7.

[34] Esteki M, Vander Heyden Y, Farajmand B, Kolahderazi Y. Qualitative and quantitative analysis of peanut adulteration in almond powder samples using multi-elemental fingerprinting combined with multivariate data analysis methods. Food Control. 2017 Dec 1;82:31-41.

[35] Laborde A, Jaillais B, Roger JM, Metz M, Bouveresse DJ, Eveleigh L, Cordella C. Subpixel detection of peanut in wheat flour using a matched subspace detector algorithm and near-infrared hyperspectral imaging. Talanta. 2020 Aug 15;216:120993.

[36] Singh P, Thawani V \& Saxena A. Deceptive food advertisements in India. Indian Journal of Basic and Applied Medical Research. 2013; 3: 132-5.

[37] Golomb BA, Evans MA, White HL, Dimsdale JE. Trans fat consumption and aggression. PloS one. 2012 Mar 5;7(3):e32175. 
[38] Nishi D, Su KP, Usuda K, Chiang YJ, Guu TW, Hamazaki K, Nakaya N, Sone T, Sano Y, Tachibana Y, Ito H. The synchronized trial on expectant mothers with depressive symptoms by omega-3 PUFAs (SYNCHRO): Study protocol for a randomized controlled trial. BMC psychiatry. 2016 Dec;16(1):1-8.

[39] Gupta N, Panchal P. Extent of awareness and food adulteration detection in selected food items purchased by home makers. Pakistan journal of nutrition. 2009; 8(5): 660-7.

[40] Tripathi M, Khanna SK, Das M. Surveillance on use of synthetic colours in eatables vis a vis Prevention of Food Adulteration Act of India. Food Control. 2007 Mar 1;18(3):211-9.

[41] Ma HL, Wang JW, Chen YJ, Lai ZT. Rapid authentication of starch adulterations in ultrafine granular powder of Shanyao by near-infrared spectroscopy coupled with chemometric methods. Food chemistry. 2017 Jan $15 ; 215: 108-15$.

[42] Liu J, Wen Y, Dong N, Lai C, Zhao G. Authentication of lotus root powder adulterated with potato starch and/or sweet potato starch using Fourier transform mid-infrared spectroscopy. Food chemistry. 2013 Dec 1;141(3):3103-9.

[43] Yang X, Guang P, Xu G, Zhu S, Chen Z, Huang F. Manuka honey adulteration detection based on near-infrared spectroscopy combined with aquaphotomics. LWT. 2020 Oct 1;132:109837.

[44] Gao B, Xu S, Han L, Liu X. FT-IR-based quantitative analysis strategy for target adulterant in fish oil multiply adulterated with terrestrial animal lipid. Food Chemistry. 2021 May 1;343:128420.

[45] Tognoli C, Saroglia M, Terova G, Gornati R, Bernardini G. Identification of fish species by 5S rRNA gene amplification. Food chemistry. 2011 Dec 15;129(4):1860-4.

[46] Kesmen Z, Celebi Y, Güllüce A, Yetim H. Detection of seagull meat in meat mixtures using real-time PCR analysis. Food Control. 2013 Nov 1;34(1):47-9.

[47] Aykas DP, Menevseoglu A. A rapid method to detect green pea and peanut adulteration in pistachio by using portable FT-MIR and FT-NIR spectroscopy combined with chemometrics. Food Control. 2021 Mar 1;121:107670. 